septa as a consequence of slime accumuletion, and later by cohesion rupture.

\section{Felix Rawitscher}

ERIKA RAWITSCHER

Botany Department,

University, São Paulo,

Brazil.

Sept. 14.

${ }^{1}$ Lofttield, J. V. G., "The Behavior of Stomata", Carnegie Inst. of Washington Pub. (1921).

'Bode, H. R., Jahrb. wiss. Bot., 62, 92 (1923).

"Dixon, H. H., "Transpiration and the Ascent of Sap in Plants" (London, 1914).

\section{Glomus Cells in the Human Choroid}

I HAVE seen hitherto unnoted large round or polyhedric cells, of $10-20 \mu$ diameter, in the outskirts of middle-sized and big choroidal arteries in the region of the posterior pole of many human eyes. These big cells are conspicuous by their clear cytoplasm, only a few of them containing small granules. The plasm is outlined by a smooth continuous cell membrane. The nuclei are stained with hæmatoxylin an even dark purple without visible chromosomes or nucleoli; they are round or oblong and situated predominantly centrally. These large cells are present relatively infrequently in normal choroid (Fig. 1), where they are found singly; they occur in groups in the media or adventitia of arteries in cases of hypertension and other circulatory disturbances (Fig. 2).

These cells correspond to von Schuhmacher's glomus cells', the so-called 'epitheloid muscle cells'. Glomus cells have been identified with the 'cushion cells' filling the lumen of arterio-venous anastomoses of certain tissues ${ }^{2}$ and are supposed to be of great biological importance ${ }^{3}$, as they are connected with the short-circuit from artery to vein, essential in many physiological and pathological processes.

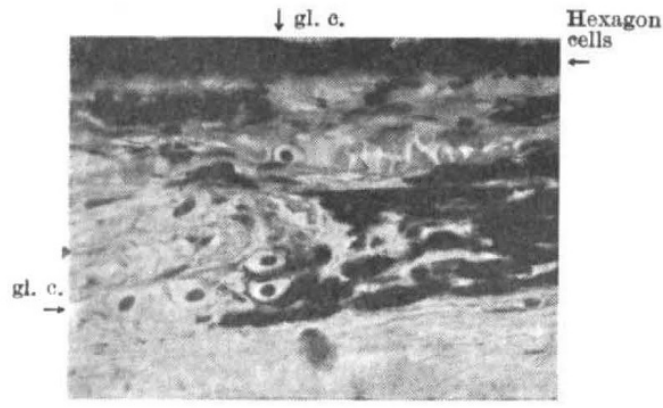
Fig. 1. Glomus cells in the choroid of a supposed normal eye.

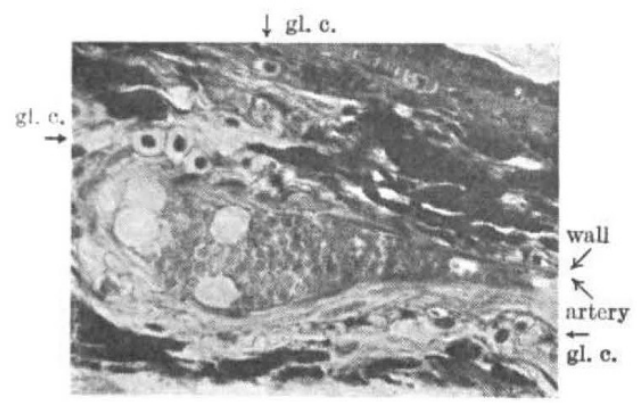

Fig. 2. Glomus cells in an arterial wall in the choroid of a hypertensive arteriosclerotic patient. $\times 150$
In none of the routine sections have I seen a lumen within the glomus groups, but their relation to the vessel wall is obvious. These cells may be the "swell cells' in the arterio-venous short-circuits, and may open these channels by shrinking, and close them by swelling, as is assumed by the majority of investigators. We cannot exclude, on the other hand, that they are contracting elements, constricting certain vessels from the outside. It is probable that both types occur side by side. In any event, although they have not been examined histologically hitherto, they are certainly present, and belong to the elaborate regulating system of choroidal blood circulation which adapts this corpus cavernosum of the eye $\theta^{4}$ admirably to the frequent changes of intra-ocular pressure.

\section{A. Loewenstein}

T'ennent Institute of Ophthalmology, University of Glasgow. Aug. 10.

1 von Schuhmacher, see Bruns' Beiträge zur klin. Chir., 159, 335 (1935). Clara, Z. Anat., 27, 246 (1927).

' Havlicek, "Hippokrates", 2 (reprint, 1929). Spanner, Gegenbauer's Jahrbuch, 69, 394 (1932). Masson, "Les glomus neuro-vasculaires" (Bermann et Cie., Paris, 1937).

- Kiss, Ophthalmologica, 108, 225 (1943).

\section{Spore Prints from Individual Phialides of Verticillium spp.}

STERILE soil-extract agar $p H 4$ (without mineral or organic additions) is allowed to set in a Petri dish. Using a fine rod finished off at the tip into a small glass bead, the agar surface is streaked with the given spore suspension or smear, care being taken to avoid breaking the surface. When phialospores are being produced in appreciable numbers, rectangular pieces of coverslip are placed flat on the surface of the agar close to and on opposite sides of the streak, and entire coverslips are then rested on them so as to cover the streak. Using a 1/5 obj. and ocular $\times 10$ the upper surface of the coverslip is first brought into focus. Downward racking with the fine adjust. ment is then continued until phislides and spores are observed at or near the underside of the coverslip. Many upwardly directed phialides will have been caused to deposit their spores against the coverslip by this means, and in many cases the points of the phialides may be observed beside their own spore or spores. Phialides at a lower focus can also be caused to deposit their spores if the lens is pressed gradually down on the coverslip by means of the fine adjustment. In fact, it is quite possible, first to observe individual phialides bearing a spore mass, and then to pick off these spores by pressing the coverslip against them. The spore or spore masses may then be observed at a higher focus lying on the coverslip, and by again focusing downwards their previous relation to the now sporeless phialide-tips may be checked.

This method has enabled me to establish clearly : (a) multiple-spore production by individual phialides of Verticillium psalliotos; (b) variation in size and shape of spores produced from the same phialide, namely, one or a few large crescent-shaped spores and a variable number of smaller crescent-shaped or oval spores. Many of the apparently oval spores are actually crescent-shaped but appear oval when viewed from the convex or opposite aspect (that is, concave or plane). Those which are truly oval are 